\title{
ANALISIS PENDAPATAN USAHATANI DAN PEMASARAN NANAS DI DESA KUALU NENAS KECAMATAN TAMBANG KABUPATEN KAMPAR
}

\author{
ANALYSIS OF BUSINESS INCOME AND MARKETING OF PINEAPPLE \\ IN KUALU NENAS VILLAGE TAMBANG DISTRICT KAMPAR REGENCY
}

\author{
Anisyananda Pauza*, Susy Edwina, Eliza \\ Program Studi Agribisnis Fakultas Pertanian Universitas Riau \\ *Email: anisyananda8@gmail.com \\ (Diterima 24-10-2021; Disetujui 15-12-2021)
}

\begin{abstract}
ABSTRAK
Tujuan penelitian ini adalah untuk menganalisis pendapatan usahatani nanas, menganalisis pemasaran nanas, dan merumuskan potensi dan kendala dalam memenuhi ketersedian nanas sepanjang tahun di Desa Kualu Nenas. Penelitian ini dilaksanakan dengan metode survey, sampel pada penelitian ini diambil sebanyak $25 \%$ dari populasi, sehingga jumlah sampel yang diambil adalah 30 petani. Hasil penelitian menunjukan pendapatan bersih yang diterima petani jenis anakan buah adalah Rp.61.450.970,04 /Ha dan petani anakan batang sebesar Rp.52.903.030,56/Ha. Nilai RCR (Return Cost Ratio) petani jenis anakan buah sebesar 3,29 dan 2,67 petani anakan batang. Hal ini berarti usahatani yang dilakukan sama-sama memperoleh keuntungan karena nilai RCR yang diperoleh besar dari $1(\mathrm{RCR}>1)$. Saluran pemasaran nanas di Desa Kualu Nenas terdiri atas 4 saluran. Margin pemasaran saluran I (Rp. 4.026,79 /Gandeng), saluran II (Rp.2.618,75 /Gandeng), saluran III (Rp.92.051,34 /Gandeng), dan saluran IV bernilai 0. Bagian terbesar yang diterima petani yaitu saluran IV $(100,00 \%)$, diikuti saluran II $(70,58 \%)$, saluran I $(60,30 \%)$, dan saluran III $(7,95 \%)$. Saluran pemasaran yang efisien yaitu saluran IV (3,03\%). Banyaknya usaha agroindustri nanas serta letak yang strategis dalam memasarkan buah nanas. Kendala yang dihadapi petani tidak adanya perjanjian tertulis lahan yang telah ditanami nanas diambil sebelum masa hak pakai.
\end{abstract}

Kata Kunci: Petani Nanas, Pendapatan, Pemasaran

\begin{abstract}
The purpose of this study was to analyze the income of pineapple farming, analyze pineapple marketing, and formulate the potential and constraints in meeting the availability of pineapple throughout the year in Kualu Pineapple Village. This research was conducted by survey method, the sample in this study was taken as much as $25 \%$ of the population, so the number of samples taken was 30 farmers. The results of the study showed that the net income received by the sapling farmers was Rp.61.450.970.04/Ha and the tillers were Rp.52.903.030.56/Ha. The value of RCR (Return Cost Ratio) for tiller type farmers is 3.29 and 2.67 tiller stem farmers. This means that the farming carried out equally gains profit because the RCR value obtained is greater than 1 (RCR> 1). The pineapple marketing channel in Kualu Nanas Village consists of 4 channels. The marketing margin for channel I (Rp.4,026.79/Gandeng), channel II (Rp.2,618.75/Gandeng), channel III (Rp.92,051.34/Gandeng), and channel IV is worth 0. The largest share received by farmers is channel IV (100.00\%), followed by channel II (70.58\%), channel I (60.30\%), and channel III (7.95\%). An efficient marketing channel is channel IV (3.03\%). The number of pineapple agroindustry businesses and the strategic location in marketing pineapples. The obstacle faced by farmers is that there is no written agreement on land that has been planted with pineapples taken before the use rights period.
\end{abstract}

Keywords: Pineapple Farmers, Income, Marketing 


\section{PENDAHULUAN}

Kampar merupakan salah satu sentra produksi nanas di Riau dan memiliki luas lahan potensial 90.624 Ha (Badan Pusat Statistik, 2019). Sentra produksi nanas di Kecamatan Tambang terdapat di Desa Rimbo Panjang dan Desa Kualu Nenas. Luas kebun nanas di Desa Kualu Nenas yaitu 805 Ha dengan hasil panen nanas \pm 67 Ton/Ha (Kantor Desa Kualu Nenas, 2019)

Budidaya nanas di Kualu Nenas belum memperhatikan penggunaan faktor produksi sesuai dengan kebutuhan tanaman untuk tumbuh dan berproduksi dengan baik. Penggunaan faktor produksi terutama pemberian pupuk belum sesuai dengan dosis yang dianjurkan. Pupuk yang umum digunakan petani hanya pupuk urea. Hanya beberapa petani yang menambahkan pupuk TSP, KCL dan NPK.

Nanas yang dihasilkan oleh petani di Desa Kualu Nenas dipasarkan melalui beberapa saluran pemasaran seperti dijual melalui perantara pedagang pengumpul, kemudian dijual ke pedagang besar, maupun dijual ke agroindustri dan konsumen langsung. Sistem penentuan harga jual dari petani ke pedagang pengumpul, yang dulu dan sekarang masih sama, yaitu dipukul rata tanpa melihat besar kecilnya ukuran nanas, sedangkan harga jual dari petani ke konsumen langsung ditentukan berdasarkan ukuran buah nanas. Harga jual nanas yang berfluktuasi menjadi permasalahan yang sering dihadapi petani. Harga di tingkat petani nanas di Desa Kualu Nenas relatif rendah jika dibandingkan dengan harga di tingkat pedagang pengumpul dan pedagang besar/eksportir. Hal ini mengakibatkan pendapatan petani relatif rendah dan kemampuan investasi juga rendah sehingga petani sulit untuk mencapai tingkat kesejahteraan yang seharusnya diharapkan petani.

Tujuan penelitian ini adalah untuk: 1) menganalisis pendapatan usahatani nanas, 2) menganalisis pemasaran nanas, 3) merumuskan potensi dan kendala dalam memenuhi ketersediaan nanas sepanjang tahun di Desa Kualu Nenas Kecamatan Tambang Kabupaten Kampar.

\section{METODE PENELITIAN}

Penelitian ini dilaksanakan di Desa Kualu Nenas Kecamatan Tambang Kabupaten Kampar Provinsi Riau. Metode yang digunakan dalam penelitian ini adalah metode survey yaitu dengan melakukan pengumpulan data berupa kuesioner. Sampel pada penelitian ini 
diambil sebanyak $25 \%$ dari 120 populasi, sehingga sampel yang diambil sebanyak 30 petani. Pengambilan sampel terhadap pedagang melalui metode snowball sampling dengan mengikuti saluran pemasaran yaitu dimulai dari petani ke pedagang pengumpul, pedagang pengecer, pedagang besar, dan agroindustri hingga sampai ke konsumen.

Metode analisis data yang digunakan untuk menjawab tujuan penelitian pertama sebagai berikut:

a) Analisis biaya produksi dihitung menggunakan rumus (Fathorrazi, 2012) :

$$
\mathbf{T C}=\mathbf{F C}+\mathrm{VC}
$$

Keterangan :

$\mathrm{VC}=$ Biaya Variabel (Rp/Ha/Tahun)

$\mathrm{FC} \quad=$ Biaya Tetap $(\mathrm{Rp} / \mathrm{Ha} / \mathrm{Tahun})$

$\mathrm{TC}=$ Total Biaya (Rp/Ha/Tahun)

b) Menganalisis nilai penyusutan peralatan digunakan rumus (Baridwan, 2010) :

$$
\text { D : } \frac{H P-N S}{n}
$$

Keterangan :

$\mathrm{D}=$ Nilai Penyusutan Alat (Rp/unit/tahun) $\mathrm{HP}=$ Harga Perolehan (Rp/unit)

NS $=$ Nilai Sisa 20\% dari harga perolehan $\mathrm{N}=$ Taksiran Umur Manfaat (Tahun)

c) Penerimaan, pendapatan bersih usahatani nanas dihitung dengan menggunakan rumus (Soekartawi, 2006) :

$$
\begin{gathered}
\text { TR }=\text { Py } \cdot \text { Y } \\
\pi=\text { TR }- \text { TC } \\
\pi=\text { Y.Py }-(\text { TFC }+ \text { TVC })
\end{gathered}
$$

Keterangan :

$\mathrm{TR}=$ Total Penerimaan $(\mathrm{Rp} / \mathrm{Ha} / \mathrm{Tahun})$

Py $=$ Harga per satuan hasil produksi

$\mathrm{Y}=$ Jumlah Produksi (Gandeng)

$\Pi=$ Keuntungan bersih $(\mathrm{Rp} / \mathrm{Ha} /$ Tahun $)$

$\mathrm{TFC}=$ Biaya Tetap Total (Rp/Tahun)

TVC $=$ Biaya Variabel Total $(\mathrm{Rp} /$ Tahun $)$

d) Efisiensi usahatani digunakan model analisis Return Cost of Ratio (RCR) (Soekartawi, 2006):

\section{$\mathbf{R C R}=\mathbf{T R} / \mathrm{TC}$}

Keterangan:

$\mathrm{RCR}=$ Return Cost Of Ratio

$\mathrm{TR}=$ Total Revenue $($ Total Penerimaan $)$

$\mathrm{TC}=$ Total Cost $($ Total Biaya $)$

Ada tiga kriteria dalam perhitungan ini, yaitu :

1. Jika $\mathrm{R} / \mathrm{C}<1$, maka usahatani yang dilakukan belum menguntungkan.

2. Jika $\mathrm{R} / \mathrm{C}>1$, maka usahatani yang dilakukan menguntungkan.

3. Jika $\mathrm{R} / \mathrm{C}=1$, maka usahatani berada pada Break Event Point.

Tujuan penelitian kedua digunakan analisis saluran pemasaran, margin dan efisiensi pemasaran. Margin pemasaran 
dihitung menggunakan rumus (Sudiyono, 2004) :

$$
\mathbf{M P}=\mathbf{P r}-\mathbf{P f}
$$

Keterangan :

$\mathrm{MP}=$ Margin Pemasaran $(\mathrm{Rp})$

$\operatorname{Pr}=$ Harga di tingkat pedagang $(\mathrm{Rp})$

Pf = Harga di tingkat petani (Rp)

Efesiensi tataniaga pemasaran diukur berdasarkan efektivitas pasar dengan menggunakan farmer's share (Sisfahyuni, 2008) :

$$
F S=\frac{\text { HLPJ }}{\text { HLPB }} \times 100 \%
$$

Dimana:

Fs = Farmer's Share $(\%)$

Hlpj = Harga produk (Rp/Gandeng)

$\mathrm{Hlpb}=$ Harga konsumen akhir $(\mathrm{Rp})$

Efisiensi pemasaran digunakan rumus (Iskandar, 2008):

$$
\boldsymbol{E P}=\frac{\mathrm{TB}}{\mathrm{TNP}} \mathbf{X} 100 \%
$$

Keterangan :

$\mathrm{EP}=$ Efisiensi pemasaran $(\%)$
$\mathrm{TB}=$ Total Biaya Pemasaran

(Rp/Gandeng)

$\mathrm{TNP}=$ Total Nilai Produk yang dibayarkan (Rp/Gandeng)

Tujuan penelitian ketiga digunakan alat analisis deskriptif untuk merumuskan potensi dan kendala dalam memenuhi ketersedian nanas sepanjang tahun, yang dilihat dari usahatani seperti: sumber modal, kepemilikan lahan, pola tanam, kepemilikan saprotan, sumber air, pengendalian OPT, penggunaan teknologi off season, dan pemasaran dilihat dari tujuan pasar, penentu harga jual, sistem pembayaran serta akses petani terhadap informasi harga.

\section{HASIL PEMBAHASAN}

\section{Usahatani Nanas}

\section{a. Biaya produksi}

Rata-rata biaya usahatani nanas di Desa Kualu Nenas dilihat pada Tabel 1.

\begin{tabular}{|c|c|c|c|c|c|}
\hline \multirow[b]{2}{*}{ No } & \multirow[b]{2}{*}{ Jenis Biaya } & \multicolumn{2}{|c|}{ Anakan Buah } & \multicolumn{2}{|c|}{ Anakan Batang } \\
\hline & & $\begin{array}{c}\text { Rata-Rata } \\
\text { Biaya(Rp/Lg) }\end{array}$ & $\begin{array}{c}\text { Rata-Rata } \\
\text { Biaya(Rp/Ha) }\end{array}$ & $\begin{array}{c}\text { Rata-Rata } \\
\text { Biaya(Rp/Lg) }\end{array}$ & $\begin{array}{c}\text { Rata-Rata } \\
\text { Biaya(Rp/Ha) }\end{array}$ \\
\hline \multirow[t]{5}{*}{1} & Biaya Tetap & & & & \\
\hline & a. Sewa Lahan & $2.642 .857,14$ & $2.000 .000,00$ & $2.777 .777,78$ & $2.000 .000,00$ \\
\hline & b. Penyusutan Alat & $89.292,06$ & $70.791,75$ & $80.022,22$ & $60.779,01$ \\
\hline & c. TKDK & $1.271 .428,57$ & $1.049 .047,62$ & $1.080 .000,00$ & $824.074,07$ \\
\hline & d. Penyusutan Tanaman & $7.112 .600,00$ & $5.307 .910,45$ & $7.112 .600,00$ & $5.307 .910,45$ \\
\hline \multirow[t]{5}{*}{2} & Biaya Variabel & & & & \\
\hline & a. Bibit & $10.290 .476,19$ & $8.023 .412,70$ & $17.638 .888,89$ & $12.444 .444,44$ \\
\hline & b. Pupuk & $2.351 .428,57$ & $3.496 .611,11$ & $1.979 .444,44$ & $2.516 .111,11$ \\
\hline & c. Ethrel & $68.047,62$ & $54.079,37$ & $66.444,44$ & $50.666,67$ \\
\hline & d. TKLK & $942.095,24$ & $747.015,87$ & $731.851,85$ & $557.407,41$ \\
\hline \multicolumn{2}{|c|}{ Total Biaya Produksi } & $24.768 .225,40$ & $20.748 .868,86$ & $31.467 .029,63$ & 23.761.393,17 \\
\hline \multicolumn{2}{|c|}{ Persentase (\%) } & 44,04 & 46,62 & 55,96 & 53,38 \\
\hline
\end{tabular}

Tabel 1. RatarRata Total Biaya Produksi Petani Nanas Anakan Buah dan Anakan Batang di Desa Kualu Nenas 
Berdasarkan Tabel 1. total biaya produksi anakan batang lebih besar dibandingkan dengan total biaya produksi yang dikeluarkan anakan buah. Hal ini dikarenakan petani anakan batang memperoleh bibit dengan harga tinggi dibandingkan anakan buah, sehingga biaya yang dikeluarkan dalam usahatani nanas anakan batang lebih tinggi.

\section{b. Analisis Pendapatan Usahatani}

Rata-rata penerimaan dan pendapatan dari usahatani nanas di Desa Kualu Nenas dapat dilihat pada Tabel 2.

Tabel 2. Rata-Rata Total Penerimaan, Total Biaya, Pendapatan dan R/C Ratio Usahatani Nanas di Desa Kualu Nenas

\begin{tabular}{lcrrr}
\hline \multirow{2}{*}{\multicolumn{1}{c}{ Uraian }} & \multicolumn{2}{c}{ Anakan Buah } & \multicolumn{2}{c}{ Anakan Batang } \\
\cline { 2 - 5 } & $\mathbf{( R p / L g )}$ & $\mathbf{( R p / H a )}$ & $\mathbf{( R p / L g )}$ & $\mathbf{R p / H a )}$ \\
\hline Total Penerimaan & $85.239 .830,36$ & $68.063 .885,42$ & $83.138 .875,00$ & $62.566 .250,00$ \\
Total Biaya Produksi & $24.768 .225,40$ & $20.748 .868,86$ & $31.467 .029,63$ & $23.761 .393,17$ \\
Pendapatan Bersih & $60.471 .604,96$ & $47.315 .016,55$ & $51.717 .845,37$ & $38.804 .856,83$ \\
R/C & & 3,29 & & 2,67 \\
\hline
\end{tabular}

Berdasarkan Tabel 2. menunjukan bahwa nilai RCR usahatani nanas di Kualu Nenas per Ha adalah sebesar 3,29 untuk petani anakan buah dan 2,67 untuk petani anakan batang. Rata-rata nilai RCR tersebut menunjukkan bahwa usahatani nanas tersebut dilihat dengan RCR lebih dari 1 atau untung, artinya setiap pengeluaran petani yang menggunakan anakan buah sebesar Rp100,00 akan memberikan keuntungan sebesar Rp3,29 dan setiap pengeluaran petani yang menggunakan anakan batang sebesar Rp100,00 akan memberikan keuntungan sebesar Rp2,67.

Menurut Siregar (2010), nanas yang dihasilkan petani responden dari masa produksi selama satu tahun sebanyak 25.192,30 buah/ha. Petani menerima harga rata-rata sebesar Rp1.000/buah.
Masa produksi selama satu tahun, petani memperoleh penerimaan sebesar Rp25.192.307,69/ha dan total biaya usahatani (Rp15.828.094/Ha) sehingga pendapatan petani (Rp9.364.214/Ha).

Nilai $\mathrm{R} / \mathrm{C}$ ratio dari usahatani nanas ini adalah 1.59 yang berarti setiap Rp 1, biaya total yang dikeluarkan akan memeroleh penerimaan sebesar $\mathrm{Rp}$ 1.59. Nilai R/C ratio yang lebih dari satu menunjukkan bahwa usahatani nanas masih memberikan keuntungan bagi petani .

\section{Pemasaran}

\section{a. Saluran pemasaran}

Saluran pemasaran nanas di Desa Kualu Nenas dapat dilihat pada Gambar 1. 


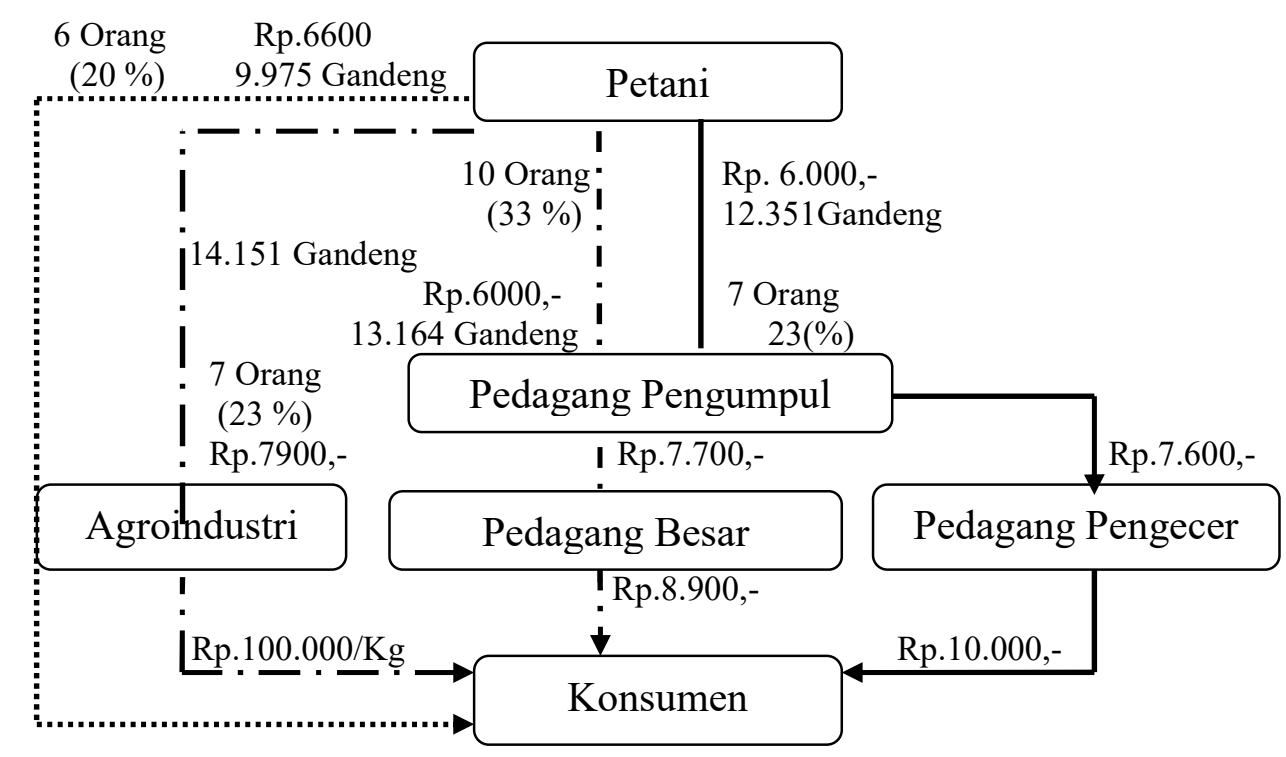

Gambar 1. Saluran Pemasaran Nanas di Desa Kualu Nenas

Keterangan :

$$
\begin{aligned}
& \longrightarrow=\text { Saluran Pemasaran I } \\
& \text { - . - . . . . = Saluaran Pemasaran II } \\
& \text { - } \cdot \text { - _ - S Saluran Pemasaran III } \\
& \text {. = Saluran Pemasaran IV }
\end{aligned}
$$

Gambar 1. menggambarkan saluran pemasaran yang dilalui petani untuk menyampaikan produk ke konsumen. Sebagian besar petani nanas menjual hasil produksi kepada pedagang pengumpul. petani cenderung lebih memilih memasarkan hasil produksi nanas ke pedagang pengumpul karena tidak memikirkan biaya pemasaran dan kerusakan buah, karena pedagang pengumpul langsung mengambil buah nanas ke kebun dan produksi yang diperoleh petani langsung habis terjual. Harga jual dari petani ke pedagang pengumpul dipukul rata tanpa melihat besar kecilnya ukuran nanas.

\section{b. Analisis Pemasaran Nanas}

Margin pemasaran adalah selisih harga yang dibayar konsumen akhir dan harga yang diterima petani produsen. Margin pemasaran yang paling tinggi adalah saluran III (Rp.92.051,34/Kg) diikuti kemudian oleh saluran I (Rp4.026,79/Gandeng) saluran II (Rp2.618,75/Gandeng) saluran terendah yaitu saluran IV bernilai 0. Analisis margin pemasaran nanas di Desa Kualu Nenas dapat dilihat pada Tabel 3.

Menurut Siregar (2010), saluran pemasaran nanas Bogor yang memiliki margin tertinggi adalah saluran II (Rp2.120) diikuti saluran I (Rp1.800) dan saluran II (Rp100). Margin pemasaran yang tinggi juga mengindikasikan keuntungan yang tinggi. Hal itu tergantung pada berapa besar biaya-biaya 
yang dikeluarkan oleh lembaga-lembaga pemasaran.

Menurut Putri (2017), nilai margin pemasaran nanas tertinggi terdapat pada
Margin terendah terdapat pada saluran I dan II yaitu sebesar Rp0, hal ini disebabkan pedagang pengumpul menjual nanas langsung ke konsumen.

saluran IV sebesar Rp6.041/Buah.

Tabel 3. Analisis Margin Pemasaran Nanas pada Saluran I, II, III, dan IV di Desa Kualu Nenas

\begin{tabular}{|c|c|c|c|c|c|}
\hline \multirow[b]{2}{*}{ No } & \multirow{2}{*}{$\begin{array}{l}\text { Keterangan } \\
\text { (Rp/Gandeng) }\end{array}$} & \multicolumn{4}{|c|}{ Saluran Pemasaran } \\
\hline & & $\mathbf{I}$ & II & III & IV \\
\hline \multirow[t]{6}{*}{$\mathrm{A}$} & Petani & - & - & - & - \\
\hline & 1. Harga Jual & $6.116,07$ & $6.281,25$ & $7.948,66$ & $6.609,38$ \\
\hline & 2. Biaya Pemasaran & - & - & 100 & 200 \\
\hline & . Transportasi & - & - & 100 & 100 \\
\hline & - Tali & - & - & - & 100 \\
\hline & 3. Penerimaan & $6.116,07$ & $6.281,25$ & $7.848,66$ & $6.409,38$ \\
\hline \multirow[t]{6}{*}{$\mathrm{B}$} & Pedagang Pengumpul & - & - & - & - \\
\hline & 1.Harga Beli & $6.116,07$ & $6.281,25$ & - & - \\
\hline & 2. Biaya Pemasaran & 100 & 115 & - & - \\
\hline & - Transportasi & 100 & 115 & - & - \\
\hline & 3. Margin Pemasaran & $1.562,50$ & $1.468,75$ & - & - \\
\hline & 4. Keuntungan & $1.462,50$ & $1.353,75$ & - & - \\
\hline \multirow[t]{7}{*}{$\mathrm{C}$} & Pedagang Pengecer & - & - & - & - \\
\hline & 1.Harga Beli & $7.678,57$ & - & - & - \\
\hline & 2. Biaya Pemasaran & 271,43 & - & - & - \\
\hline & - Transportasi & 171,43 & - & - & - \\
\hline & - Tali & 100 & - & - & - \\
\hline & 3. Margin Pemasaran & $2.464,29$ & - & - & - \\
\hline & 4. Keuntungan & $2.192,86$ & - & - & 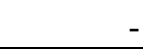 \\
\hline \multirow[t]{8}{*}{$\mathrm{D}$} & Pedagang Besar & - & - & - & - \\
\hline & 1.Harga Beli & - & $7.750,00$ & - & - \\
\hline & 2. Harga Jual & - & $8.900,00$ & - & - \\
\hline & 3. Biaya Pemasaran & - & 330 & - & - \\
\hline & · Transportasi & - & 230 & - & - \\
\hline & - Tali & - & 100 & - & - \\
\hline & 4. Margin Pemasaran & - & $1.150,00$ & - & - \\
\hline & 5. Keuntungan & - & 820 & - & - \\
\hline \multirow[t]{9}{*}{$\mathrm{E}$} & Agroindustri & - & - & - & - \\
\hline & 1.Harga Beli & - & - & $7.948,66$ & - \\
\hline & 2. Biaya Pemasaran & - & - & $42.375,00$ & - \\
\hline & - Transportasi & - & - & 250 & - \\
\hline & - Bongkar Muat & - & - & 250 & - \\
\hline & - Penyusutan & - & - & $1.875,00$ & - \\
\hline & - Biaya Produksi & - & - & $40.000,00$ & - \\
\hline & 3. Margin Pemasaran & - & - & $92.051,34$ & - \\
\hline & 4. Keuntungan & - & - & $50.051,34$ & . \\
\hline \multirow[t]{2}{*}{$\mathrm{F}$} & Konsumen Akhir & - & - & - & . \\
\hline & Harga Beli & $10.142,86$ & $8.900,00$ & $100.000,00$ & $6.609,38$ \\
\hline $\mathrm{G}$ & Total Biaya Pemasaran & 371,43 & 445,00 & $42.100,00$ & 200,00 \\
\hline $\mathrm{H}$ & Total Margin Pemasaran & $4.026,79$ & $2.618,75$ & $92.051,34$ & $\mathbf{0}$ \\
\hline $\mathrm{J}$ & Keuntungan Total & $3.655,36$ & $2.173,75$ & 92.051,34 & $6.409,38$ \\
\hline
\end{tabular}

Farmer's share dan nilai efisisiensi

pemasaran dapat dilihat pada Tabel 4. 
Tabel 4. Farmer's Share dan Nilai Efisiensi Pemasaran pada Saluran Pemasaran Nanas di Desa Kualu Nenas

\begin{tabular}{crr}
\hline $\begin{array}{c}\text { Saluran } \\
\text { Pemasaran }\end{array}$ & Farmer's Share & $\begin{array}{c}\text { Efisiensi } \\
\text { Pemasaran }\end{array}$ \\
\hline I & 60,30 & 3,66 \\
II & 70,58 & 5,00 \\
III & 7,95 & 42,10 \\
IV & 100,00 & 3,03 \\
\hline
\end{tabular}

Hasil analisis dari keempat saluran pemasaran pada Tabel 4, bagian terbesar yang diterima petani terdapat pada saluran IV yaitu sebesar $100 \%$. Saluran tersebut harga yang dijual dan dibeli oleh konsumen sama dan tidak melibatkan lembaga pemasaran sehingga semua keuntungan dapat langsung diterima oleh petani. Saluran terendah yaitu saluran III sebesar 7,98\%.

Menurut Putri (2017), farmer's share tertinggi terdapat pada saluran pemasaran I (petani-konsumen) dan II (petani-pedagang olahan nanas) sebesar 100\%. Hal ini dikarenakan pada kedua saluran tersebut harga yang dijual dan dibeli oleh konsumen sama dan tidak melibatkan lembaga pemasaran sehingga semua kentungan dapat langsung diterima oleh petani, sedangkan terndah terdapat pada saluran IV yaitu sebesar $28,93 \%$.

Saluran pemasaran yang lebih efisien adalah pada saluran IV dengan nilai efisiensi sebesar 3,03\%. Karena petani mampu menjual secara langsung kepada konsumen tanpa adanya pedagang perantara dan mampu menjualnya dengan mengeluarkan biaya pemasaran dengan sekecil mungkin. Menurut Rahmawati (2013), saluran yang relatif lebih efisien adalah saluran pemasaran nanas yang tidak melibatkan lembaga perantara melainkan petani menjual langsung hasil produksi kepada konsumen (direct selling).

\section{Potensi dan Kendala dalam Usahatani} dan Pemasaran Nanas

\section{a. Usahatani}

Desa Kualu Nenas merupakan desa penghasil nanas terbanyak di Kecamatan Tambang. Cara budidaya tanaman nanas dengan tidak melakukan penanaman ulang dan hanya menjadikan anakan tanaman nanas sebagai penghasil produksi. Hal ini dikarenakan usahatani nanas merupakan sumber utama pencaharian petani. Menurut Tamba (2017), petani di Desa Tangkit Baru, juga melakukan kegiatan persiapan tanaman nanas hanya ketika petani membongkar tanamannya dan akan menanamnya kembali, ada juga petani yang tidak melakukan hal tersebut. Hal ini dikarenakan nanas yang mereka tanam tetap akan berbuah dengan hanya sekali tanam saja. karena petani mendapatkan warisan lahan yang sudah ditanami nanas 
akan tetap berbuah dengan hanya sekali tanam dan tidak perlu penanam ulang

Sumber modal petani berasal dari modal sendiri dan pinjaman dari kelompok tani. Petani yang meminjam pada kelompok tani yaitu anggota kelompok tani itu sendiri. Besar pinjaman yang diberikan oleh kelompok tani dilihat dari besarnya produksi dan pendapatan petani tersebut.

Petani yang status hak pakai memiliki kendala yang dihadapi seperti: tidak adanya perjanjian tertulis antara pemilik dan penggarap, sehingga petani merasa dirugikan ketika hasil nanas bagus. Lahan di Desa Kualu Nenas juga semakin sedikit. Tahun 2012 luas kebun nanas $1050 \mathrm{Ha}$ (Kantor Desa, 2012), dan saat ini luas lahan nanas hanya $805 \mathrm{Ha}$ (Kantor Desa, 2019). Penurunan ini dikarenakan lahan banyak dialih fungsikan menjadi perkebunan kelapa sawit, karet dan perumahan.

Pola tanam budidaya nanas yang dilakukan petani secara monokultur (single cropping). Hal ini dilakukan karena tanaman nanas tidak bisa terlindungi dari sinar matahari, tanaman nanas yang di tanam secara tumpangsari akan menghasilkan buah yang lebih kecil dibandingkan dengan ditanam secara monokultur. Penelitian ini didukung oleh
Duriah (2018), yang menyatakan bahwa "Pola tumpangsari diterapkan karena dapat memanfaatkan lahan secara optimum. Terdapat perbedaan hasil antara nanas monokultur dan nanas tumpangsari yaitu ukuran buah yang berbeda, nanas monokultur menghasilkan buah yang lebih besar dibandingkan nanas tumpangsari”.

Sarana produksi pertanian dalam usahatani nanas antara lain, cangkul, handsprayer, parang, sabit, keranjang panen, dan lain-lain. Mayoritas petani mendapatkan sarana produksi pertanian yaitu dari membeli secara pribadi. Tanaman nanas termasuk tanaman yang tahan kekeringan. Pengairan tanaman nanas hanya mengandalkan air hujan, petani membuat parit guna untuk megalirkan air hujan Apabila tanaman nanas tergenang air maka tanaman nanas akan busuk sehingga diperlukan saluran air berupa parit. Berdasarkan keadaan di lapangan saluran air atau parit tidak dirawat dengan baik.

Hama pada tanaman nanas di lokasi penelitian secara spesifik hanyalah hama babi dan tikus karena lokasi kebun nanas yang dekat dengan daerah hutan serta kebun nanas yang penuh dengan rumput liar dan semak. Tindakan pengendalian hama yang dilakukan umumnya dengan 


\section{ANALISIS PENDAPATAN USAHATANI DAN PEMASARAN NANAS \\ DI DESA KUALU NENAS KECAMATAN TAMBANG KABUPATEN KAMPAR \\ Anisyananda Pauza, Susy Edwina, Eliza}

membuat pagar dan parit disekeliling kebun nanas dan dilakukan petani pada saat membuka kebun nanas, sehingga kegiatan pengendalian hama dan penyakit yaitu perawatan pagar dan parit atau saluran pengairan dilakukan dengan frekuensi satu (1) kali dalam satu tahun.

Penyakit yang biasanya menyerang nanas yaitu penyakit yang diakibatkan oleh bakteri, petani menyebut dengan penyakit tahi lalat. Tindakan pengendalian penyakit ini tidak dilakukan oleh petani dan membiarkan tanaman terserang penyakit. Hal ini dilakukan petani karena tanaman yang terserang penyakit masih mampu menghasilkan buah nanas, walaupun dengan kualitas yang rendah.

Menurut Sari et al (2014), salah satu kendala produksi nanas adalah serangan penyakit busuk hati. Busuk hati yang disebabkan oleh patogen jamur Phytophthora sp. Pengendalian penyakit busuk hati pada tanaman nanas dapat dilakukan dengan penggunaan fungisida, pengaturan sistem drainase yang baik, dan peningkatan kesehatan tanaman dengan pemberian pupuk serta bahan organik seperti kompos.

Perkembangan teknologi of season Teknologi memunculkan buah di luar musim dapat menstabilkan produksi komoditi musiman tersedia sepanjang tahun (Gunadi, 2017). Penggunaan ethrel salah satunya dapat mengatur waktu panen yang diinginkan, sesuai dengan permintaan konsumen dan teknis pemberian yang dilakukan. Petani tidak menggunakan ethrel pada seluruh tanaman dan cenderung secara bertahap, agar dapat dipanen setiap minggu, serta meminimalisir risiko harga anjlok ketika panen raya. Petani lebih bergantung pada penggunaan ethrel dari pada budidaya tanaman nanas secara alami. Hal ini dikarenakan permintaan akan komoditas nanas selalu terjadi setiap saat. Satu bulan petani panen 3 sampai 4 kali.

\section{b. Pemasaran}

Mayoritas petani menjual hasil usahatani melalui perantara pedagang pengumpul, kemudian menjual nanas ke pedagang pengencer, pedagang besar, dan sebagian petani menjual hasil nanas ke pedagang agroindustri maupun dijual langsung ke konsumen. Banyaknya pabrik pengolahan, menjadikan nilai tambah bagi petani dan pengrajin serta letak yang strategis sehingga petani dengan mudah memasarkan hasil produksi nanas.

Penentuan harga jual antara petani dan pedagang pengumpul dilakukan kesepakatan bersama, yaitu sistem penetapan harga nanas petani dengan 
pedagang dipukul rata harga buah, tanpa melihat besar kecil buah nanas. Petani tidak memiliki bargaining position yang tinggi dalam penentuan harga jual buah. Ini disebabkan petani memiliki ikatan yang kuat antara petani dan pedagang seperti meminjam modal kepada pedagang, selain itu hubungan keluarga atau kerabat dekat, sehingga petani tidak dapat menjual hasil nanas ke pedagang lain.

Sistem pembayaran dilakukan secara langsung atau dibayar sebagian hingga produk laku terjual yang umumnya hanya membutuhkan waktu dua hari. Namun, petani cenderung mencari pembeli yang dapat membayar secara tunai. Hal ini dikarenakan petani membutuhkan uang tersebut untuk modal pemeliharaan nanas. Informasi saat ini sangat mudah didapatkan karena ditunjang dengan sarana transportasi dan alat telekomunikasi yang memadai.

Berbeda dengan penelitian Sinaga \& Dewi (2016), bahwa informasi harga pasar tidak mudah didapatkan, karena tidak adanya kerja sama antara pedagang pada pasar yang satu dengan pedagang pada pasar yang lain, ini dikarenakan jauhnya lokasi yang tidak ditunjang dengan sarana transportasi dan telekomunikasi yang memadai.

\section{KESIMPULAN DANS ARAN}

\section{Kesimpulan}

Pendapatan yang diperoleh petani yang menggunakan jenis anakan buah di Desa Kualu Nenas sebesar Rp61.450.970,04/ha dan Rp52.903.030,56/ha/tahun untuk anakan batang. Nilai RCR usahatani nanas per Ha untuk petani anakan buah sebesar 3,29 dan 2,67 petani anakan batang. Hal ini berarti usahatani yang dilakukan sama-sama memperoleh keuntungan serta dikatakan efisien karena nilai RCR yang diperoleh besar dari 1 (RCR $>1)$.

Saluran pemasaran nanas di Desa Kualu Nenas terdiri atas 4 saluran pemasaran. Margin pemasaran saluran I (Rp4.026,79/Gandeng), saluran II (Rp2.618,75/Gandeng), saluran III (Rp92.051,34/Gandeng), saluran IV bernilai 0. Bagian yang diterima petani yang terbesar adalah saluran IV (100,00\%), diikuti saluran II (70,58\%), saluran I (60,30\%), saluran III (7,95\%). Saluran pemasaran yang efisien adalah saluran IV sebesar 3,03\%. Karena petani mampu menjual secara langsung kepada konsumen tanpa adanya pedagang perantara dan mampu menjualnya dengan mengeluarkan biaya pemasaran dengan sekecil mungkin. 


\section{ANALISIS PENDAPATAN USAHATANI DAN PEMASARAN NANAS \\ DI DESA KUALU NENAS KECAMATAN TAMBANG KABUPATEN KAMPAR \\ Anisyananda Pauza, Susy Edwina, Eliza}

Potensi yang dirasakan petani nanas adalah banyaknya usaha agroindustri nanas di desa tersebut serta letak yang strategis dalam memasarkan buah nanas. Kendala yang dihadapai petani dalam status kepemilikan lahan dengan tidak adanya perjanjian tertulis sehingga Pemilik lahan mengambil alih lahan sebelum masa hak pakai selesai.

\section{Saran}

Petani perlu melakukan perawatan terhadap tanaman sesuai dengan petunjuk budidaya yang telah dianjurkan seperti melakukan pemupukan sesui anjuran teknis budidaya untuk meningkatkan jumlah produksi. Peran pemerintah atau instansi terkait juga sangat diperlukan untuk melakukan sosialisasi dan pelatihan, selain itu petani dapat melakukan pengolahan terhadap buah nanas untuk meningkatkan nilai jual terhadap nanas tersebut.

\section{DAFTAR PUSTAKA}

Badan Pusat Statistik. (2019). Provinsi Riau Dalam Angka 2019.

Baridwan, Z. (2010). Sistem Akuntansi Penyusunan Prosedur dan Metode (5th ed.). BPPE.

Duriah, E. (2018). Analisis Komparatif Pendapatan Riil Usahatani Nanas Monokultur Terhadap Tumpang Sari Nanas pada Karet TBM; studi kasus di Desa Senuro Timur Kecamatan Tanjung Batu
Kabupaten ogan ilir. Universitas Sriwijaya.

Fathorrazi. (2012). Teori Ekonomi Mikro. Graha Ilmu.

Gunadi, I. G. A. (2017). Sejarah dan Perkembangan Produksi Tanaman diluar Musim. Prosiding Discussion Issue and Technolog: Pengembangan Teknologi Budidaya di Luar Musim Sebagai Alternatif Mewujudkan Indonesia Berdaulat Pangan. Discussion Issue And Technology- HIMAGROTEK.

Iskandar. (2008). Metodologi Penelitian Pendidikan dan Sosial (Kualitatif dan Kuantitaif). Gaun Persada Press.

Putri, C. A. (2017). Analisis Pemasaran Dan Pendapatan Usahatani Nanas Di Kecamatan Cijeruk Kabupaten Bogor. Institut Pertanian Bogor.

Rahmawati, A. (2013). Analisis Efisiensi Pemasaran Nanas Studi Kasus di Desa Cipelang, Kecamatan Cijeruk, Kabupaten Bogor. Institut Pertanian Bogor.

Sari, G. I., Aini, L. Q., \& Abadi, A. L. (2014). Pengaruh Pemberian Kompos Terhadap Perkembangan Penyakit Busuk Hati (Phytophthora sp.) pada Tanaman Nanas (Ananas comosus). 2, 71-76.

Sinaga, S. C., \& Dewi, N. (2016). Pemasaran Buah Nanas (Kajian Struktur, Perilaku, dan Penampilan Pasar) di Desa Kualu Nenas Kecamatan Tambang Kabupaten Kampar. Jurnal Ilmiah Pertanian, 13(1), 38-50.

Siregar, Erik Laksamana. (2010). Analisis Pendapatan Usahatani dan Pemasaran Nanas Bogor di Desa Sukaluyu, Kecamatan Taman Sari, Kabupaten Bogor. Institut Pertanian Bogor.

Sisfahyuni. (2008). Efisiensi Tataniaga Komoditi Kakao Biji Asal Kabupaten Parigi Moutong 
Propinsi Sulawesi Tengah. Jurnal Agrisains, 9(3), 150-159.

Soekartawi. (2006). Analisis Usahatani. UI Press.

Sudiyono, A. (2004). Pemasaran Pertanian (Kedua). UMM Press.
Tamba, L. R. (2017). Hubungan Karakteristik Petani dengan Penerapan Teknik Usahatani Nanas di Desa Tangkit Baru Kecamatan Sungai Gelam Kabupaten Muaro Jambi. 